\title{
Reduction of Cracking and Shrinkage in Compressed Clay Beams during Drying
}

\author{
NAWAB ALI LAKHO*, MUHAMMAD AUCHAR ZARDARI*, AND NAEEM AZIZ MEMON** \\ RECEIVED ON 28.05.2015 ACCEPTED ON 16.09.2015
}

\begin{abstract}
Uncontrolled evaporation of moisture from compressed clay beams can cause surface cracks, resulting in reduction of strength. This paper presents various treatments applied to clay beams during the process of casting, compacting and drying in order to curtail the possibility of cracking and to decrease percentage of drying shrinkage. Following treatments were applied to the beams during casting and drying: (i) a steel plate and double layer of plastic sheet was provided between the beam and the plank, (ii) the beam was enveloped with a propylene fabric sheet during casting and (iii) beams were covered with plastic sheet during drying. Using these treatments, the clay beams were cast and compacted at various intensities of compaction. The results show that the drying shrinkage was reduced to minimum and the cracks were curtailed. The rate of drying shrinkage was decreased depending upon the level of compaction. Thus at the higher degree of compaction, more density of clay beams was achieved, which resulted in higher degree of compressive strength in baked and unbaked state.
\end{abstract}

Key Words: Compressed Earth Blocks, Affordable Houses, Compaction, Indigenous Clay, Drying Shrinkage and Cracks.

\section{INTRODUCTION}

$\mathrm{S}$ helter is one of the basic requirements of human being besides food. The modern tendency is towards construction of structures with reinforced cement concrete and steel which is not affordable for the poor masses [1]. Thus low cost and indigenous material of construction is to be sought and used in original or modified state for the construction of affordable houses. Clay is low cost and indigenous material of construction and is used, in different forms, for construction of low cost houses since ages [2].

Clay has been used in the form of moulded earth block called bricks in baked and unbaked state since the time of Moses [3]. In order to increase the performance of moulded earth blocks in unbaked state, it was tamped and compressed since $18^{\text {th }}$ century [4] and is called CEB (Compressed Earth Blocks).

In order to use indigenous clay as low cost material of construction, beams were cast and compacted from a mixture of clay and pit sand in a ratio of 70:30, in addition to $22 \%$ of potable water. During the process of drying of these clay beams, shrinkage cracks occurred due to evaporation of moisture. Due to this shrinkage, tensile stresses may develop. If these tensile stresses are constrained, they get intensify and reach its tensile

* Assistant Professor, Department of Civil Engineering, Quaid-e-Awam University of Engineering, Science \& Technology, Nawabshah. ** Associate Professor, Department of Civil Engineering, Mehran University of Engineering \& Technology, Jamshoro. 
strength, as a result cracks may occur [5-9]. Consequently the mechanical strength is significantly reduced [10]. Due to complex behaviour of soil, cracking is also affected by factors such as mineral composition, content of clay, humidity, temperature and relative thickness of layers etc [11-15]. The object of this study is to decipher the treatments by application of which the problems of drying shrinkage and cracking in the clay beams could be curtailed.

\section{MATERIALS AND METHOD}

\subsection{Compacting System}

A stiff and strong mechanical system was designed and fabricated to cast and compact clay beams. This mechanized system is shown in Fig 1. The details of which are presented elsewhere [16]. The moist clay beams were compacted at various intensities of loading which varied from 1.94-7.2 MPa. The compacting load on the beam was applied with the help of a wooden plunger with compacting area of $150 \times 2000 \mathrm{~mm}$. This wooden plunger was flexibly pinned to four strong hydraulic jack cylinders with the help of a steel plate, as shown in Fig 1. The hydraulic jacks were powered by a controlled displacement plunger hydraulic pump, run by 5 horse power, 3-Phase electric motor.

\subsection{Beam Specimen}

The indigenous clay was quarried at the depth of more than $1200 \mathrm{~mm}$ lest the particles of organic matter like leaves and roots of the plants, debris and aggregates may not be mixed with the quarry.

Indigenous clay was mixed with pit sand in the ratio of $70: 30$, in addition to $22 \%$ of potable water, in a pan mixer for a period of 15 minutes. A detailed study regarding the percentage of pit sand and its effect on the compressive strength of the baked clay was conducted by Ansari [17]. This study [17], suggested that $30 \%$ of pit sand mixed with $70 \%$ of indigenous clay gave: (i) maximum cube crushing strength of baked clay and (ii) the percentage of shrinkage was decreased with increase of ratio of pit sand. Hence, the same ratio was used in this study. Generally, workability of clay depends on percentage of moisture. At the moisture content of $22 \%$, it was very easy to mix properly this clay pit sand mixture in a pan mixer and cast the beams easily.

This moist clay was allowed to mature for 24 hours. The moist clay-sand mixture was filled in the mould in five equal layers and each layer was properly tamped. The mould was filled to its total depth of $460 \mathrm{~mm}$ and railed in to the compacting chamber of the system for the compaction of beam.

The section of beam of $150 \times 300 \mathrm{~mm}$ is considered to be standard laboratory size for testing concrete beams. Beams of $4000 \mathrm{~mm}$ length are generally used in various engineering construction works. It is difficult to cast,

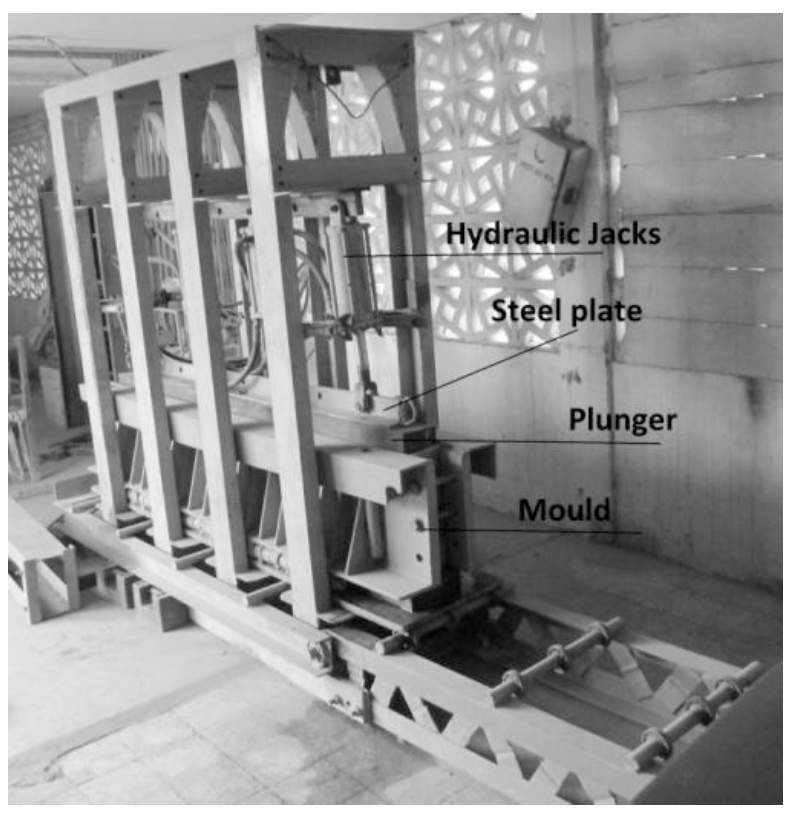

FIG. 1. MECHANIZED SYSTEM FOR CASTING AND COMPACTING CLAY BEAMS

Mehran University Research Journal of Engineering \& Technology, Volume 35, No. 3, July, 2016 [p-ISSN: 0254-7821, e-ISSN: 2413-7219] 
compact, bake, transport and test clay beams of this much length. Therefore, in this study, beams of size 150x300x2000mm were cast, compacted and tested.

In order to decrease the percentage of cracking and to curtail possibility of cracking in the beams, following treatments were applied during casting and drying process:

A finished steel plate underneath a double layer of plastic sheet was provided between the beam and the wooden plank on which the beam was cast (Fig. 2).The double layer of plastic sheet was provided between the steel plate and the beam in order to provide a friction free medium. This steel plate was provided to reduce the possibility of adhesion of clay with wooden plank during the process of drying shrinkage.

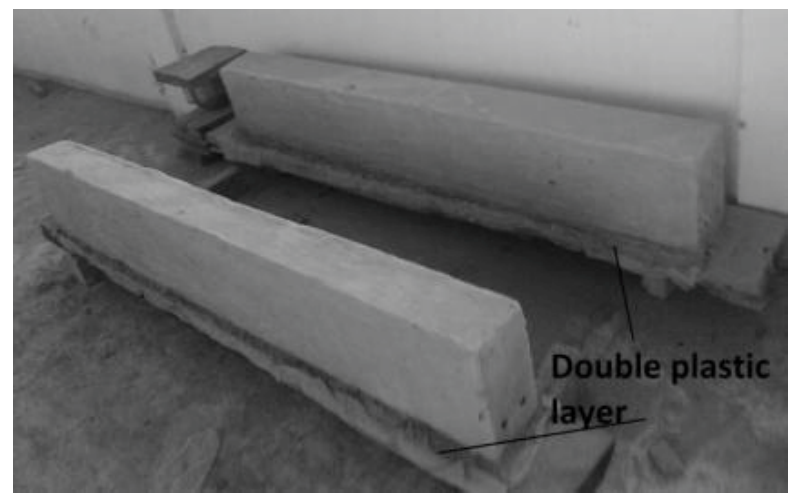

FIG. 2. STEEL PLATE UNDERNEATH A DOUBLE LAYER OF THIN PLASTIC SHEET PROVIDED BETWEEN PLANK AND $B E A M$

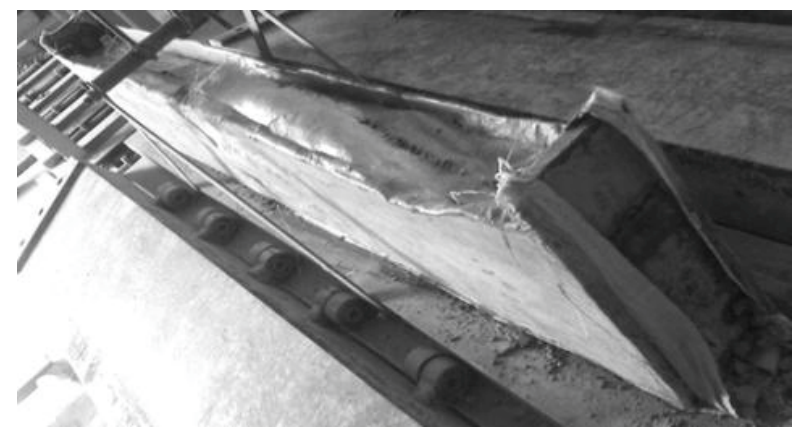

FIG. 3. CLAY BEAM ENVELOPED WITH PROPYLENE FABRIC SHEET DURING CASTING (ii) The beam was properly enveloped with a propylene fabric sheet during the process of compaction (Fig. 3). The compaction of beam using this treatment is called filter press condition.

(iii) During drying, the compacted moist clay beams were covered with plastic sheet (Fig 4).

Using these treatments clay beams were cast and compacted at $3,4,5,6$, and 7.2 $\mathrm{MPa}$.

\section{RESULTS AND DISCUSSION}

After applying the compacting load of $1.94 \mathrm{MPa}$, the beam was demoulded and allowed to dry in shed. On drying it showed vertical cracks which further opened with time as shown in Fig. 5. The cracking was due to un-controlled rate of evaporation of moisture from the surface of clay beam. To curtail the possibility of cracking of clay beam during drying, it was necessary to reduce the rate of evaporation. Thus the other beams were covered properly with a plastic sheet (Fig. 4) to control and reduce rate of evaporation. With this treatment, the cracking in the beam was eliminated except at the base which was in contact with the wooden plank (Fig. 6). A smooth steel plate with a double layer of plastic sheet was provided between the beam and wooden plank (Fig. 2) to eliminate the possibility of cracking at the base. With the application of these two treatments, none of the beams cracked during the process of drying (Fig. 7). With this treatment of covering the clay beam with plastic sheet during drying, the time of drying was increased.

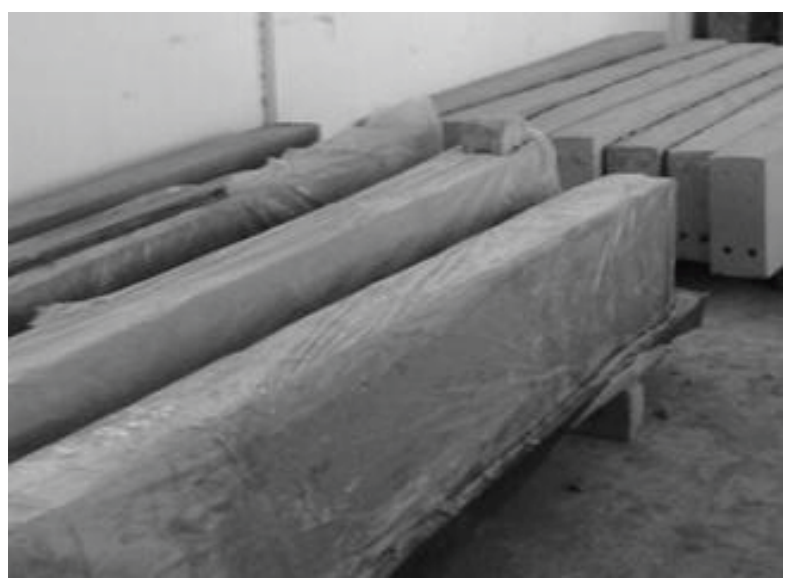

FIG. 4. THE MOIST CLAY BEAMS COVERED WITH PLASTIC SHEET DURING DRYING

Mehran University Research Journal of Engineering \& Technology, Volume 35, No. 3, July, 2016 [p-ISSN: 0254-7821, e-ISSN: 2413-7219] 
Due to oozing out of moist clay from the crevices and openings, when no treatment was applied to the beam during casting and compacting, the degree of compaction could not be increased above $1.94 \mathrm{MPa}$. Thus, in this condition, the density of clay beam could not be increased.

In order to achieve more density of the beam, it is to be compacted at higher degree of compaction. To curtail the possibility of oozing out of moist clay from the mould, the beam was properly enveloped in a Polypropylene fabric sheet. This treatment worked well. With this treatment, it was possible to compact the beam above the threshold value of $1.94 \mathrm{MPa}$. After only a few minutes of suspension of load on the beam, water was seen dripping out of the mould. In this way, the added water in the clay was pressurized to expel out of the beam. The amount of

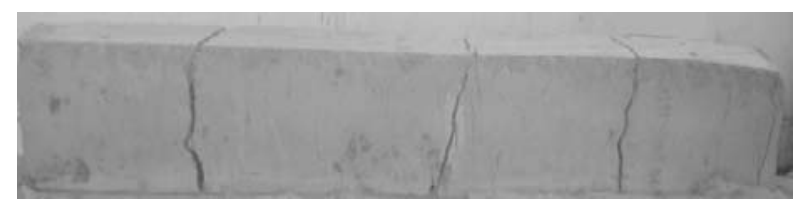

FIG. 5. DRYING CRACKS IN CLAY BEAM

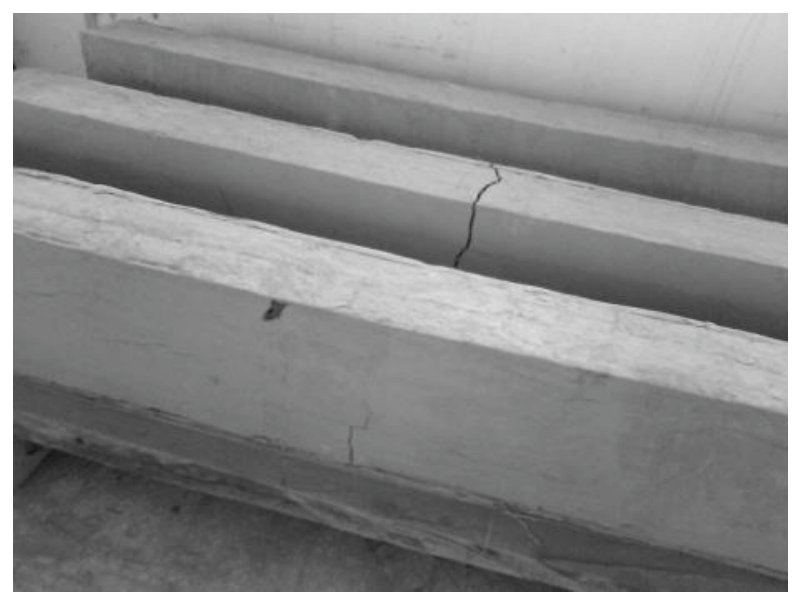

FIG. 6. DRYING CRACKS IN BASE OF THE CLAY BEAM

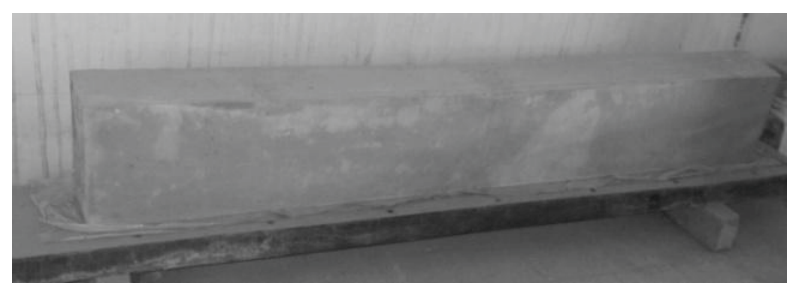

FIG. 7. CLAY BEAM WITHOUT ANY SHRINKAGE CRACKS water expelled depended upon the intensity of compaction. As the intensity of compaction on the beam was increased, the rate of water expelled out of the beam was also increased. To observe the behaviour of the beam at various intensities of compaction, it was compacted at $3,4,5,6$, and 7.2 $\mathrm{MPa}$.

Twenty four clay beams were cast and compacted at above mentioned levels of compaction and dried in shed using the suggested treatments. After complete drying of these beams, longitudinal shrinkage was measured and plotted against respective compacting load as shown in Fig. 8. It can be observed that due to the intensity of compaction, water was pressurized to ooze out the moist clay of beam. The quantity of this water depends upon the intensity of compaction. At smaller rate of compaction above $1.94 \mathrm{MPa}$, there was no expulsion of moisture from the moist clay beam. All the water, which was added to clay during mixing, remained in same quantity in the beam after compaction at this load. Therefore, before complete drying, all the mixed quantity of water evaporated, which resulted in maximum shrinkage of $6.4 \%$. At the rate of compaction above1.94 $\mathrm{MPa}$, a certain amount of water was compelled to ooze out depending upon the intensity of compaction. Thus, at increased rate of compaction, more amount of water was expelled out of moist clay beam. Consequently, at the higher intensity of compaction of 7.2 $\mathrm{MPa}$, minimum shrinkage of $0.64 \%$ was observed.

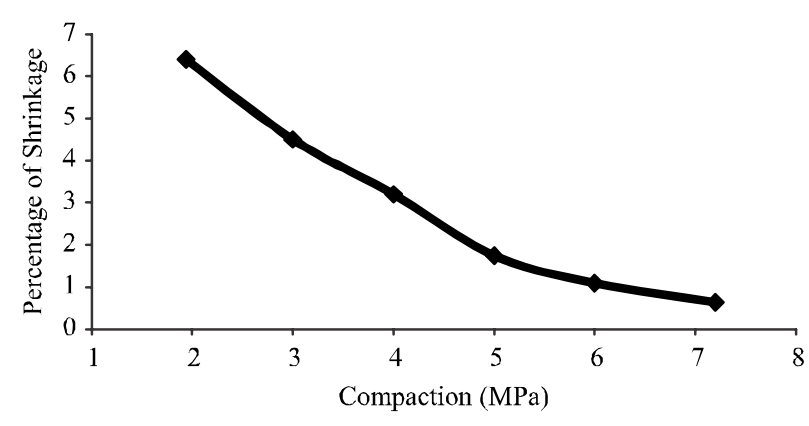

FIG. 8. INTENSITY OF COMPACTION VERSUS PERCENTAGE OF SHRINKAGE IN CLAY BEAMS

Mehran University Research Journal of Engineering \& Technology, Volume 35, No. 3, July, 2016 [p-ISSN: 0254-7821, e-ISSN: 2413-7219] 


\section{CONCLUSIONS}

The main conclusions drawn from this study are:

(i) The clay beams were cast, compacted and dried in shed showed a number of vertical cracks.

(ii) When the beams were cast and compacted using the devised treatments, possibility of cracking was completely curtailed and shrinkage was also decreased depending upon the level of compaction.

(iii) When the beam was compacted in filter press condition; water, added in the clay during mixing, was made ooze out. The amount of this water expelled due to compaction depended upon the degree of compaction.

(iv) The beams shrunk averagely up to $6.4 \%$ when they were compacted at $1.94 \mathrm{MPa}$. When the degree of compaction was increased to $7.2 \mathrm{MPa}$, the percentage of shrinkage was decreased to $0.64 \%$.

\section{ACKNOWLEDGEMENTS}

The authors would like to thank Quaid-e-Awam University of Engineering, Science \& Technology, Nawabshah, and Mehran University of Engineering \& Technology, Jamshoro, Pakistan, for their support to conduct this research study.

\section{REFERENCES}

Ansari, A.A., Bhatti, N.K., and Bhutto, M.A., "Suitability of Pre-Perforated Post-Reinforced Baked Clay Beam Panels for Low Cost Housing", American Journal of Civil Engineering, Volume 1, No. 1, pp. 6-15, 2013.

[2] Calkins, M., "Materials for Sustainable Sites: A Complete Guide to the Evaluation, Selection, and Use of Sustainable Construction Materials”, John Wiley and Sons, 2008.
[3] Holy Quran, Surah Al-Qassas, verse 38.

[4] Deboucha, S., and Hashim, R., "A Review on Bricks and Stabilized Compressed Earth Blocks", Scientific Research and Essays, Volume 6, No. 3, pp. 499-506, 2011.

[5] Costa, S., Kodikara, J., and Shannon, B., "Salient Factors Controlling Desiccation Cracking of Clay in Laboratory Experiments", Geotechnique, Volume 63, No. 1, pp. 18-29, 2013.

[6] Tang, C.S., Shi, B., Liu, C., Suo, W.B., and Gao, L., "Experimental Characterization of Shrinkage and Desiccation Cracking in Thin Clay Layer", Applied Clay Science, Volume 52, No. 1, 69-77, 2011.

[7] Trabelsi, H., Jamei, M., Zenzri, H., and Olivella, S., "Crack Patterns in Clayey Soils: Experiments and Modeling”, International Journal for Numerical and Analytical Methods in Geomechanics, Volume 36, No. 11, pp. 1410-1433, 2012.

[8] Lakshmikantha, M.R., Prat, P.C., and Ledesma, A., "Experimental Evidence of Size Effect in Soil Cracking", Canadian Geotechnical Journal, Volume 49, No. 3, pp. 264-284, 2012.

[9] Peron, H., Hueckel, T., Laloui, L., and Hu, L.B., "Fundamentals of Desiccation Cracking of Fine-Grained Soils: Experimental Characterization and Mechanisms Identification", Canadian Geotechnical Journal, Volume 46, No. 10, pp. 1177-1201, 2009.

[10] Look, B., "Handbook of Geotechnical Investigation and Design Tables", CRC Press, 2014.

[11] Tang, C., Shi, B., Liu, C., Gao, L., and Inyang, H., "Experimental Investigation of the Desiccation Cracking Behavior of Soil Layers During Drying", Journal of Materials in Civil Engineering, Volume 23, No. 6, pp. 873-878, 2011.

[12] Nahlawi, H., and Kodikara, J., "Laboratory Experiments on Desiccation Cracking of Thin Soil Layers", Geotechnical and Geological Engineering, Volume 24, No. 6, pp. 1641-1664, 2006. 
[13] Rodríguez, R., Sánchez, M., Ledesma, A., and Lioret, A., "Experimental and Numerical Analysis of Desiccation of Amining Waste", Canadian Geotechnical Journal, Volume 44, No. 6, pp. 644-658, 2007.

[14] Tang, C., Shi, B., Liu, C., Zhao, L., and Wang, B.J., "Influencing Factors of Geometrical Structure of Surface Shrinkage Cracks in Clayey Soils", Engineering Geology, Volume 101, pp. 204-217, 2008.

[15] Tang, C.S., Cui, Y.J., Tang, A.M., Shi, B., "Experimental Evidence on the Temperature Dependence of Desiccation Cracking Behavior of Clayey Soils", Engineering Geology, Volume 114, Nos. 3-4, pp. 261-266, 2010.
[16] Lakho, N.A., Zardari, M.A., Memon, M., and Saand, A., "Design and Fabrication of a Mechanized System for Casting and Compacting 1 Laboratory Size Clay Beams", Scientia Iranica, International Journal of Science and Technology, Accepted for publication, 2015.

[17] Ansari, A.A., "Experimental Study of the Behaviour of Pre-Perforated Post-Reinforced Baked Clay Panels of Beams", Ph.D. Thesis, Quaid-e-Awam University of Engineering, Science \& Technology, Nawabshah, Pakistan, 2008. 